\title{
Integrating Wasthiyah Paradigm to the Issuance of COVID-19 Fatwa; Indonesia Case
}

\author{
Abdul Syatar1, Achmad Abubakar2, Muhammad Majdy Amiruddin ${ }^{3}$, Chaerul \\ Mundzir ${ }^{4}$, Muammar Bakry ${ }^{5}$
}

1,2,5Fakultas Syariah dan Hukum, Universitas Islam Negeri Alauddin Makassar, Indonesia

${ }^{3}$ Fakultas Ekonomi dan Bisnis Islam, IAIN Parepare, Indonesia

${ }^{4}$ Fakultas Adab dan Humaniora, Universitas Islam Negeri Alauddin Makassar, Indonesia

\begin{tabular}{l} 
Info Artikel \\
\hline Keywords: \\
COVID-19, Fatwa, MUI, \\
Wasathiyah. \\
\\
Kata kunci: \\
COVID-19, Fatwa, \\
Wasathiyah. \\
MUI, \\
Corresponding Author: \\
Abdul Syatar, E-mail: \\
abdul.syatar@uin- \\
alauddin.ac.id \\
P-ISSN: 1412-6605 \\
E-ISSN: 2301-6426 \\
\hline
\end{tabular}

\begin{abstract}
This article aims to integrate the wasathiyah paradigm of the Majelis Ulama Indonesia (MUI) fatwa product and the reality of religious social issues in the midst of the pandemic coronavirus disease 2019 (COVID-19). This article adopts the normative-sociological approach. This article found that MUI fatwa products acted on strong aspects of moderation (wasathiyah), not just issuing fatwas. Various aspects of considerations (al-muwazanat) in fatwa products are marked by revealing strict arguments by expressing the opinions of the Qur'an, sunna, ijma, qiyas, the opinion of the Imam of the school and credible scholars and the views of other experts who support the issuance of fatwa in accordance with the needs of Muslims. The Washatiyah paradigm of MUI fatwa product is not influenced by political interests. It is in accordance with the maqashid al-shari'ah. The paradigm of MUI fatwa was reflected when recommending to Muslims to support and obey the government.
\end{abstract}

\begin{tabular}{l}
\hline Abstrak \\
\hline Artikel ini bertujuan untuk mengintegrasikan paradigma \\
wasathiyah produk fatwa Majelis Ulama Indonesia (MUI) dan \\
realitas persoalan sosial keagamaan di tengah wabah penyakit \\
coronavirus 2019 (COVID-19). Artikel ini mengadopsi \\
pendekatan normatif-sosiologis. Artikel ini menemukan \\
bahwa produk fatwa MUI bertindak atas dasar aspek \\
moderasi (wasathiyah) yang kuat, tidak hanya mengeluarkan \\
fatwa. Berbagai aspek pertimbangan (al-muwazanat) dalam \\
produk fatwa ditandai dengan terungkapnya dalil-dalil yang \\
tegas dengan mengutarakan pendapat Alquran, sunnah, ijma, \\
qiyas, pendapat Imam mazhab dan ulama yang kredibel serta \\
pandangan orang lain. ahli yang mendukung dikeluarkannya \\
fatwa yang sesuai dengan kebutuhan umat Islam. Paradigma \\
Washatiyah produk fatwa MUI tidak dipengaruhi oleh \\
kepentingan politik. Itu sesuai dengan maqashid al-shari'ah. \\
Paradigma fatwa MUI tercermin saat merekomendasikan \\
umat Islam untuk mendukung dan menaati pemerintah.
\end{tabular}




\section{Introduction}

Muslims around the world including Muslims in Indonesia feel the impact caused by the coronavirus disease 2019 (COVID-19). The religious social life of Muslims was 'slightly disturbed' during the COVID-19 pandemic. Some Muslims perform ritual worship activities in mosques or affordable places before this outbreak occurs. Meanwhile, the worship rituals are limited only at home, although most mosques have been reactivated during the new normal period. ${ }^{1}$

Fatwas are very important in supporting the development of Islamic values ${ }^{2}$. Fatwa of Majelis Ulama Indonesia (MUI) product can also be controversial which triggers a space for discussion and dialogue among religious groups in Indonesia ${ }^{3}$. Muslims need fatwa as a legal solution that occurs in the middle of society. Fatwa acts not only as a reference source for religious social guidance. In fact, fatwa products become historical records which are a source of reference to the condition of the people at a certain time. ${ }^{4}$ Thus, the fatwa plays one of its important roles as an instrument of social change. Fatwa becomes a link between religious idealism and the reality of social change and becomes a driver of social change through the authority of ulama or mufti (individually and institutionally) to carry out social engineering in order to direct, change and improve the state of society that needs. ${ }^{5}$

Muslims in Indonesia vary in addressing restrictions or prohibitions of worship in the mosque. Some supports the limitation, some opposes. They consider worship in the mosque something that must be done, both before and during the COVID-19 period. Some has no views because of lack of understanding of religious aspects. Even so, Muslims are still obliged to continue religious activities at home.

MUI responded by issuing fatwas on various situations affecting the socioreligious faiths of Indonesian Muslims caused by COVID-19. 6 The fatwa product issued by MUI Fatwa Commission proved to be effective in providing solutions to Muslims.

The wasathiyah (moderate) paradigm is an absolute indication that is rooted in the fatwa product issued by MUI. Therefore, Muslims are expected to return

\footnotetext{
1 Abdul Syatar, Muhammad Majdy Amiruddin, and Arif Rahman, 'Darurat Moderasi Beragama Di Tengah Pandemi Corona Virus Desease 2019 (Covid-19)', KURIOSITAS: Media Komunikasi Sosial Dan Keagamaan, 13.1 (2020), 1-13.

2 Sofian Al Hakim, 'Analytical Framwork In Studiy of Fatwas on Shariah Economics', AHKAM, 19.2 (2019), 315-30.

${ }^{3}$ Mun'Im Sirry, 'Fatwas and Ttheir Controversy: The Case of the Council of Indonesian Ulama (MUI)', Journal of Southeast Asian Studies, 44.1 (2013), 100-117.

4 Zaidah Nur Rosidah, 'Coherence of the Rules of Sharia Against Pancasila', Bestuur, 8.1 (2020), 40 <https://doi.org/10.20961/bestuur.v8i1.42723>.

${ }^{5}$ Niki Alma Febriana Fauzi, 'Fatwa Di Indonesia: Perubahan Sosial, Perkembangan, Dan Keberagaman', Jurnal Hukum Novelty, 8.1 (2017), 108-21.

${ }^{6}$ Majelis Ulama Indonesia, 'MUI Bahas Pola Ibadah Masa Pemberlakuan New Normal', MUI Digital, 2020 <https://mui.or.id/berita/28117/mui-bahas-pola-ibadah-masa-pemberlakuan-new-normal/>.
} 
the "sacred value" of religious rituals they performed as they did before COVID19. The value of sacredness in no way diminishes in the slightest considering the fatwa issued by MUI.

For instance, based on MUI Fatwa No. 14 of 2020 concerning The Operation of Worship in a Situation of the COVID-19 Outbreak, MUI forbade who are exposed to COVID-19 to pray in congregation in a mosque due opens the chance for transmission. Jum'ah prayers are replaced with dhuhr prayers independently because Jum'ah prayers of worship involving many people are feared to have a shock effect on other Muslims.

During this pandemic, MUI productively issues fatwas in response to problems faced by Muslims. MUI enacted Fatwa Number 18 of 2020 concerning Guidelines for The Management of Jenazah (Tajhiz Al-Jana'iz) Muslims Who Infected with COVID-19. MUI Fatwa became the fruit of ijtihad in delivering messages of revelation to Muslims in Indonesia, especially related to legal issues desired by Shari'a. Therefore, not all people and Islamic-based social organizations can issue fatwas and talk about the Sharia without having the capability and understand the appropriate ijtihad method. Enlightening and wasathiyah fatwas are needed by Muslims. Thus, MUI should also issue a fatwa wasathiyah to respond to the needs of the Muslim community, not fatwa that creates conflict in the community.

MUI must be able to translate the transformation of religious social change as a result of cultural dynamics in society. Transformation of change meant in the middle of a pandemic is MUI's response to the paradigm of the habits of the people who run social-religious before the pandemic takes place. As such, it is hoped that MUI fatwa product will be a guide for the ummah in overcoming religious problems during the pandemic. This article aims to integrate wasatiyah paradigm to the issuance of Fatwa COVID-19.

This research adopted library research and analytical descriptive method by looking at MUI fatwa product documents on the official website, www.mui.or.id, using the normative-sociological approach. Primary data is obtained from a variety of credible and up-to-date literature, such as books/journals and reputable journals. Secondary data found from supporting information such as websites and such. Finally, it was presented with a strong analytical instrument based on normative arguments

\section{Results and Discussion}

\section{The Essence of Fatwa in Indoensia}

At the beginning of the reform era, MUI seemed confused and adapted for the changes that had to be accepted. At that time, MUI did not focus on producing fatwas but supporting the legitimacy of several policies by 
President Habibi. It made MUI look pragmatic. ${ }^{7}$ Unlike before reform era, MUI fatwa was more politically inclined. Political influence during the new order influenced MUI fatwa product ${ }^{8}$. Thus, giving impact to fatwa products that are not substantial to the needs of Muslims.

The existence of MUI fatwa products in Indonesia is important in realizing national and state life, more specifically in the socio-religious context of Muslims. ${ }^{9}$ The fatwa product becomes a reference for Muslims in order to prevent the arbitrariness of certain groups or individuals in carrying out religious rituals.

MUI exists in Indonesia in the role of khadim al-ummah (servant/guide of the ummah), waratsah al-anbiya (generation of the Prophets), the successor to the mission of the treatise of the Messenger of Allah. and provide the movement of islah wa tajdid (peace and renewal) as well as enforcers amar makruf and nahi munkar. ${ }^{10}$ The function of MUI is urgent because it can provide fatwas and advice on religious and social issues to the government and the people. MUI can be a link between the ulema and the government to the wider community.

MUI must be able to be the endeavor of Muslims in realizing Islam as rahmatan lil alamin. The existence of MUI as a community movement is no different from other mass organizations among Muslims. MUI becomes an autonomous body and upholds the spirit of independence. ${ }^{11}$ The independence of MUI must also be stated in the fatwa product issued, not merely displaying fatwa products with the absence of flexibility.

The existence of MUI in the field of religion and politics must be in line and go hand in hand with the initial goal of forming the Unitary State of Indonesia. MUI must play a role in protecting, guarding and broadcasting the early concepts of Islam reflecting the values of islah (peace), tasamuh (tolerance), nationalism, unity, justice, democracy, upholding human rights and MUI can purify Islamic teachings as rahmatan lil alamin. MUI can break away from practical political interests ${ }^{12}$.

\footnotetext{
7 Moch Nur Ichwan, Towards a Puritanical Moderate Islam: The Majelis Ulama Indonesia and The Politics of Religious Orthodoxy, ed. by Martin van Bruinessen, Contemporary Developments in Indonesian Islam: Explaining the 'Conservative Turn' (Singapura: ISEAS-Yusof Ishak Institute, 2013).

8 Nadirsyah Hosen, '9. Fatwa And Politics in Indonesia', in Shari'a and Politics in Modern Indonesia, 2018 $<$ https://doi.org/10.1355/9789812305206-012>.

9 Slamet Suhartono, 'Eksistensi Fatwa Majelis Ulama Indonesia Dalam Perspektif Negara Hukum Pancasila', Al-Ihkam: Jurnal Hukum \& Pranata Sosial, 12.2 (2018), 448 <https:// doi.org/10.19105/al-ihkam.v12i2.1255>. 10 Rico Novianto Ali Abdillah, 'Lembaga Quasi Non-Governmental Organization (Quango) Dalam Sistem Ketatanegaraan Indonesia: Majelis Ulama Indonesia', Jurnal Hukum Dan Pembangunan, 49.1 (2019), 110-35 <https://doi.org/10.1017/CBO9781107415324.004>.

11 Majelis Ulama Indonesia, 'Produk Fatwa MUI', 2020.

12 Jeanne Francoise, 'Pemikiran Politik Islam Modern: Peran Majelis Ulama Indonesia', The 1st UICIHSS (International Conference on Islamic Humanities and Social Sciences), 2017.
} 
MUI fatwa product becomes the opinion or decision of MUI regarding the problems of Muslims. Thus, MUI fatwa product is not binding in absolute terms but adhered to by Muslims who have ties to MUI. MUI fatwa products do not have the legality to force people to obey them. However, MUI fatwa products can be adhered to when the results are in line with the wastathiyah principle.

The fatwa product produced by MUI is not a state law that has sovereignty to be forced upon Muslims in Indonesia. In fact, there are no sanctions for Muslims who do not run MUI fatwa product. The fatwa product is the substance of not more than just opinions or thoughts, both from the person of the ulema and the institution of the ulama, may be followed or ignored ${ }^{13}$. Even though MUI is not a state institution, but their fatwa products can be used as a reference in religious life. MUI fatwa products do not involve blindness nor violate the human rights of Muslims. Fatwas produced through in-depth and adequate studies and research related to public matters.

Mahfud MD explained that Islamic law is living law. Thus, living law has not been officially enforced by the state. Its enforcement cannot be imposed with heteronomous sanctions or sanctions imposed by the state ${ }^{14}$. Muslims are implementing the fatwa as a form of religious awareness independently, not a state's legal obligation. ${ }^{15}$

It is undeniable that the conservative ijtihad paradigm has given rise from conservative fiqh as well as being unable to form a dialectic between fiqh principles and traditional values that occur in society ${ }^{16}$. Thus, MUI fatwa product consisting of wasathy values can at least block the Muslims who lead to the radical movements and terrorism.

\section{Fatwa on COVID-19}

The government officially announced that the co-19 pandemic was endemic in Indonesia on Monday, March 2, 2020. Since then, Muslims have been wary of the huge impact this pandemic has caused. One of the impacts felt by Muslims is the 'disruption' of the social joints of religious rituals.

MUI responded quickly to Muslim unrest by issuing several fatwas relating to COVID-19. The earliest, MUI response by issuing fatwa No. 14 of 2010 concerning the Implementation of Worship in the Situation of the COVID-19

\footnotetext{
13 Ainun Najib, 'Fatwa Majelis Ulama Indonesia Dalam Perspektif Pembangunan Hukum Responsif', 6.2 (2012), 393-405.

${ }^{14}$ Moh Mahfud MD, ‘Fatwa MUI Dan Living Law Kita', Media Indonesia, 2016.

${ }^{15}$ Hendry Julian Noor, Kardiansyah Afkar, and Henning Glaser, 'Application of Sanctions Against State Administrative Officials Failing to Implement Administrative Court Decisions', Bestuur, 9.1 (2021), 53-67.

16 Moh Dahlan and Zakiyuddin Baidlawy, 'Gus Dur' s Ijtihād Paradigm of Contemporary Fiqh in Indonesia The Problem of Pluralism in Human Life Is Faced by Not Only Indonesia but of Indonesia ' s Reformist Figures Who Has Embarked on the Reform Is Abdurrahman Wahid (Gus Dur ). Gus Dur Has Evolve', 29.2 (2019), 167-88 <https://doi.org/http://dx.doi.org/10.21580/ahkam.2019.29.2.4193 Copyright>.
} 
Plague on March 16, 2020. This fatwa performs the detail explanation of the propositions, both from the Koran, sunna, opinions of the scholars and the rules - the law of fiqh. Therefore, based on MUI Fatwa No. 14 of 2020 concerning The Operation of Worship in a Situation of the COVID-19 Outbreak, MUI decides nine legal decisions. The most interesting legal decree is that the regions with uncontrolled spread of COVID-19 must replace the implementation of the Jum'ah Prayers with the dhuhr Prayer in their respective residences. That certainly triggers a diverse response from Muslims themselves. However, the fatwa product broke a negative response for Muslims who insisted on continuing to carry out Jum'ah prayers at the mosque.

MUI response was by issuing MUI Fatwa No. 17 of 2020 concerning Prayers for Health Workers Who Wear Personal Protective Equipment (PPE) in the middle of caring for and handling COVID-19 patients on March 26, 2020. MUI in the fatwa decided 11 legal provisions. ${ }^{17}$ There are some interesting legal provisions to be considered for Muslim medical staff who treat COVID-19 patients. Medical personnel who are on duty within the span of two prayers, may pray according to the provisions, prayers in dhuhr with basic prayers (taqdim and ta'khir) and evening prayers and evening prayers (taqdim and ta'khir). They may also perform tayammum as a substitute for wudu for prayers in a state of facing difficulties in removing the PPE. Medical personnel may repeat the prayer (i'adah al-shalah) after serving. MUI fatwa provides for strengthening the understanding of fiqh for medical personnel continuing to carry out the task of handling patients affected by Co-19 without neglecting the ritual prayer services. Jurisprudence provides an alternative solution in the form of rukhsah for medical staff on duty. 18

MUI produce Fatwa Number 18 of 2020 concerning Guidelines for Handling of Corpses (Tajhiz al-Janaiz) Infected by COVID-19 on March 27, 2020. MUI revealed that Muslims who died because of COVID-19 were included as martyrs of the afterlife with provisions on corpse rights by complying with established health protocols. The philosophy of the fatwa reinforces the understanding that co-19 is a very dangerous disease. Provisions regarding the obligation to the bodies exposed to COVID-19 besides based on religious instructions, also carried out in accordance with medical protocols. For instance, bathing, reliving, obeying and burying are

${ }^{17}$ Lego Karjoko and others, "Patent Policy on The Pharmaceutical Sector in Indonesia', 23.5 (2020), 1-13 $<$ https:// www.abacademies.org/articles/patent-policy-on-the-pharmaceutical-sector-in-indonesia9670.html>.

${ }^{18}$ Muhamad Mahrus Setia Wijaksana, 'Implementation of Criminal Case Trials Through a Teleconference by Prosecutors with a Progressive Legal Approach Muhamad', Journal of Morality and Legal Culture, 1.2 (2020), 93-102 <https://doi.org/10.20961/jmail.17i1.41087>. 
carried out by medical officers who are Muslim in accordance with religious and medical provisions. ${ }^{19}$

Therefore, Muslims who happen to be family members become victims of COVID-19 must at least realize that the management of their bodies is different from who are not exposed to COVID-19. With the management of such a body, it does not reduce the sanctity of the obligation for those who die due to co-19.

MUI also enacted MUI Fatwa No. 23 of 2020 concerning Utilization of Zakat, Infaq and Sadaqah Assets for the Overcoming of the 19th Covid Outbreak and its aplied on April 16, 2020. The fatwa provides an explanation to Muslims that the zakat assets for the eradication of the COVID-19 outbreak may be allowed with the provisions of fiqh zakat. Alms wealth can be paid and distributed quickly, do not have to wait for haul (1 year) if it reaches its Nisab. Zakat Al-Fitr can be paid and distributed since the beginning of Ramadan does not have to wait until the most desirable time, i.e., the night of Eid. The fatwa encourages Muslims who can fulfill and distribute their zakat quickly, according to the Nisab for the benefit of the people affected by the economy due to co-19. Likewise, the fatwa stressed paying zakat fitrah early which changed the habits of the majority of Muslims in paying zakat fitrah usually occurs eid al-fitr night. It shows that the aspects of the benefit are absolute and MUI priorities in bringing forth fatwa products during the COVID-19 pandemic. ${ }^{20}$

Furthermore, MUI enacted MUI Fatwa No. 28 of 2020 concerning Guidance on Takbir and Eid Al-Fitr Prayer During the COVID-19 Pandemic on May 13, 2020 M/ 20 Ramadan $1441 \mathrm{H}$. The fatwa resulted in a legal decision on permissibility to carry out Eid al-Fitr prayers at each residence with or wihout preacher. In general, the ritual activities of Ramadan and Eid al-Fitr may be carried out in the mosque, but in the area with co-19 pandemic has high risk to transmit, it remains forbidden. MUI fatwa indicates that there is a rukhshah in religious teachings must be understood by Muslims. Muslims are emphasized not to impose their desire to continue carrying out the Eid al-Fitr prayers in mosques or fields due the the high risk of co-19 transmission.

The latest fatwa product of MUI is MUI Fatwa No. 31 of 2020 concerning the Implementation of Jum'ah Prayers and Pilgrims to Prevent COVID-19 Epidemic Transmission on June 4, 2020. The legal provisions in the fatwa permit the application of phsical distance during prayer in congregation by stretching saf without reducing the priority of congregation. Certain mosques may perform Jum'ah prayers with ta'addud Jumaah (performing Jumaah

${ }_{19}$ Wulandari Berliani Putri and others, 'Medicolegal Perspective on Physician-Induced Demand Issue', Bestuur, 9.1 (2021), 77-89.

${ }^{20}$ Nurfaika Ishak, Rahmad Ramadhan Hasibuan, and Tri Suhendra Arbani, 'Bureaucratic and Political Collaboration Towards a Good Governance System', Bestuur, $8.1 \quad$ (2020), 19 <https://doi.org/10.20961/bestuur.v8i1.42922>. 
several times in the same time), such as in musalla, fields, buildings, halls and such. However, there was a disagreement between MUI Fatwa Commission with two views. First, Muslims may carry out Jum'ah prayers a shift model with legal provisions. Second, Muslims establish dhuhr prayers, both individually and in congregation because they consider the Jum'ah prayers to be invalid. The fatwa came out as a response to the anxiety of the people about the implementation of Jum'ah prayers and congregation in conditions before the new normal with medical protocols such as widening saf, wearing a mask when praying and expressing the capacity due to maintaining distance (physical distancing).

\section{The Wasathiyah Philosophy behind Fatwa COVID-19}

Methodologically, fatwas can be classified into three categories. The altaqyid wa al-tasydid method, the strictest one, the al-mubalagah fi tasahul method, the loosest one, and the wasathy al-mu'tadil method, the moderate one ${ }^{21}$. Of the three types of fatwas, the third method is widely and appropriately used by contemporary fatwa scholars. This has been performed by MUI.

Indonesia is a country with the various religion, culture, race and ethnicity. In fact, the largest part of Muslims must provide a role in stabilizing the life of the nation and state 22 . The potential for Muslims runs progressively even if Indonesia got hit by a COVID-19 plague pandemic. MUI should provide its own role and space by prioritizing the principle of wasathiyah in their fatwa products. Muslims can follow the fatwa product massively.

The polemic has dragged on amid the situation of the Islamic community in the midst of this pandemic. For instance, conditions that force Jum'ah prayers are not carried out and with different rules than before when the initial appearance of COVID-19. Pros and cons continue to be debated by Muslims in public spaces between forcing the will to continue to carry out religious orders without any difference and performing the ritual activitis following the health protocol initiated by the authority to avoid transmission of COVID-19.

Therefore, prevention measures against COVID-19 disease must be maximized immediately ${ }^{23}$. MUI fatwa product can be recommended to the government as a material consideration in making regulations. The

${ }_{21}$ Mayyadah, 'Kaidah Fleksibilitas Fatwa (Studi Terhadap Fatwa Ulama-Ulama Kontemporer)' (UIN Alauddin Makassar, 2013).

22 Busyro, Aditiya Hari Ananda, and Adlan Sanur Tarihoran, 'Moderasi Islam (Wasathiyyah) Di Tengah Pluralisme Agama Indonesia', FUADUNA: Jurnal Kajian Keagamaan Dan Kemasyarakatan, 03.01 (2019).

23 Dalinama Telaumbanua, 'Urgensi Pembentukan Aturan Terkait Pencegahan Covid-19 Di Indonesia', Qalamuna; Jurnal Pendidikan, Sosial Dan Agama, $12.1 \quad$ (2020), 59-70 <https://doi.org/https://doi.org/10.37680/qalamuna.v12i01.290>. 
implementation of the Large-scale Social Limitation (PSBB) regulation must have benefited the community. ${ }^{24}$

Muslims must know that the method of determining the fatwa, among others; The opinion of the Imam of the schools and scholars who are compatible is the first thing to refer, the law of related problem is clearly conveyed properly, and the fatwa must always look at the benefit of the public and in accordance with the maqashid al-shari'ah ${ }^{25}$. MUI Fatwa Commission must listen and consider the opinions of experts in the fields relating to the issues to be discussed before deciding on the fatwa, so that the resulting fatwa is systematic and appropriate ${ }^{26}$. Thus, the fatwa guidelines have tafsihily (systematic), argumentative principles which are based on the arguments of syara, waqi'iyah (according to contextuality-reality) and tathbiqy (applicative).

MUI provides interpretations to maintain Islamic conservatism ${ }^{27}$. COVID19 became a globalized pandemic not only in Indonesia, so as to continue to awaken the religious enthusiasm of Muslims. MUI gave a moderate interpretation of fatwa products to safeguard Islam and the personalities of Muslims in accordance with Islamic traditions for years in Indonesia. MUI fatwa upholds flexibility in the midst of the tumult of the 19th pandemic.

Based on MUI Fatwa No. 17 of 2020, as an instance of the flexibility of the fatwa reflecting moderate value of MUI, it is possible for medical officers who are on duty to pay even though there is a lot of water around because there are fears of COVID -19 transmission. In fact, the medical officer may establish prayers without removing PPE clothing. The fatwa should be listened to and considered for health workers as part of continuing their religious activities without disregarding Shari"s orders. ${ }^{28}$

MUI fatwa products around the co-19 pandemic at least amounted to six fatwas as of this writing was completed. The author indicates that MUI fatwa product combines moderate and reality attitudes in line with the benefit of Muslims in Indonesia. Muslims who need religious views about a pandemic should refer to the existing MUI fatwa product

${ }^{24}$ Abdul Kadir Jaelani, I Gusti Ayu Ketut Rachmi Handayani, and Lego Karjoko, 'Development of Tourism Based on Geographic Indication towards to Welfare State', International Journal of Advanced Science and Technology, 29.3s (2020), 1227-34.

25 Ijtima' Ulama Se-Indonesia, Keputusan Ijtima' Ulama Komisi Fatwa Se-Indonesia Pertama Tahun 2003 (Jakarta, 2003).

26 Al Fakhri Zakirman, 'Metodologi Fatwa Majelis Ulama Indonesia', Al-Hikmah, 10.2 (2016), 157-72 <https://doi.org/10.24260/al-hikmah.v10i2.615>.

27 Mohamad Abdun Nasir, 'The 'Ulamā', Fatāwā and Challenges to Democracy in Contemporary Indonesia', Islam and Christian-Muslim Relations, 2014 <https:/ / doi.org/10.1080/09596410.2014.926598>.

28 Devi Triasari, 'Right to Sanitation: Case Study of Indonesia', Journal of Human Rights, Culture and Legal System, 1.3 (2021). 


\section{Conclusion}

MUI fatwa products relating to the COVID-19 pandemic containing wasathiyah is needed by Muslims in the midst of the difficult situation felt by Muslims during the pandemic. MUI's interpretation of the reality when the plague struck was appropriate. The fatwa product is based on rigorous considerations with the adoption of the arguments of the Koran, sunna, ijmak, qiyas, the opinion of the Imam of the school of thought and scholars who are credible and the views of other experts who support the issuance of fatwas in accordance with the needs of Muslims. The paradigm of MUI fatwa was reflected when recommending to Muslims to support and obey the government circulars to conduct physical distancing and social distancing. MUI fatwa product regarding COVID-19 advocates that Muslims must "give in" in fulfilling their religious ritual obligations by complying with health protocols without reducing the sanctity of the ritual worship they perform. Muslims are not encouraged to go too far and impose their will in carrying out services in the midst of the co-19 pandemic.

\section{Refrences}

Ali Abdillah, Rico Novianto, 'Lembaga Quasi Non-Governmental Organization (Quango) Dalam Sistem Ketatanegaraan Indonesia: Majelis Ulama Indonesia', Jurnal Hukum Dan Pembangunan, 49.1 (2019), 110-35 <https://doi.org/10.1017/CBO9781107415324.004>

Busyro, Aditiya Hari Ananda, and Adlan Sanur Tarihoran, 'Moderasi Islam (Wasathiyyah) Di Tengah Pluralisme Agama Indonesia', FUADUNA: Jurnal Kajian Keagamaan Dan Kemasyarakatan, 03.01 (2019)

Dahlan, Moh, and Zakiyuddin Baidlawy, 'Gus Dur' s Ijtihād Paradigm of Contemporary Fiqh in Indonesia The Problem of Pluralism in Human Life Is Faced by Not Only Indonesia but of Indonesia' s Reformist Figures Who Has Embarked on the Reform Is Abdurrahman Wahid (Gus Dur ). Gus Dur $\begin{array}{llll}\text { Has } & \text { Evolve', } & 29.2 & \text { (2019), }\end{array}$ <https://doi.org/http://dx.doi.org/10.21580/ahkam.2019.29.2.4193 Copyright>

Dalinama Telaumbanua, 'Urgensi Pembentukan Aturan Terkait Pencegahan Covid-19 Di Indonesia', Qalamuna; Jurnal Pendidikan, Sosial Dan Agama, 12.1 (2020), $59-70$ <https://doi.org/https://doi.org/10.37680/qalamuna.v12i01.290>

Fauzi, Niki Alma Febriana, 'Fatwa Di Indonesia: Perubahan Sosial, Perkembangan, Dan Keberagaman', Jurnal Hukum Novelty, 8.1 (2017), 108-21 Francoise, Jeanne, 'Pemikiran Politik Islam Modern: Peran Majelis Ulama Indonesia', The 1st UICIHSS (International Conference on Islamic Humanities and Social Sciences), 2017 
Hosen, Nadirsyah, '9. Fatwa And Politics in Indonesia', in Shari'a and Politics in Modern Indonesia, 2018 <https:/ / doi.org/10.1355/9789812305206-012>

Ichwan, Moch Nur, Towards a Puritanical Moderate Islam: The Majelis Ulama Indonesia and The Politics of Religious Orthodoxy, ed. by Martin van Bruinessen, Contemporary Developments in Indonesian Islam: Explaining the 'Conservative Turn' (Singapura: ISEAS-Yusof Ishak Institute, 2013)

Indonesia, Majelis Ulama, 'Produk Fatwa MUI', 2020

Ishak, Nurfaika, Rahmad Ramadhan Hasibuan, and Tri Suhendra Arbani, 'Bureaucratic and Political Collaboration Towards a Good Governance System', Bestuur, 8.1 (2020),

<https:/ / doi.org/10.20961/bestuur.v8i1.42922>

Jaelani, Abdul Kadir, I Gusti Ayu Ketut Rachmi Handayani, and Lego Karjoko, 'Development of Tourism Based on Geographic Indication towards to Welfare State', International Journal of Advanced Science and Technology, 29.3s (2020), 1227-34

Karjoko, Lego, Said Gunawan, A L Sentot Sudarwanto, Heriyanti, Zaidah Nur Rosidah, I Gusti Ayu Ketut Handayani, and others, "Patent Policy on The Pharmaceutical Sector in Indonesia', 23.5 (2020), 1-13 <https:/ / www.abacademies.org/articles/patent-policy-on-thepharmaceutical-sector-in-indonesia-9670.html>

Majelis Ulama Indonesia, 'MUI Bahas Pola Ibadah Masa Pemberlakuan New Normal', MUI Digital, 2020 <https://mui.or.id/berita/28117/mui-bahaspola-ibadah-masa-pemberlakuan-new-normal/>

Mayyadah, 'Kaidah Fleksibilitas Fatwa (Studi Terhadap Fatwa Ulama-Ulama Kontemporer)' (UIN Alauddin Makassar, 2013)

Moh Mahfud MD, 'Fatwa MUI Dan Living Law Kita', Media Indonesia, 2016

Muhamad Mahrus Setia Wijaksana, 'Implementation of Criminal Case Trials Through a Teleconference by Prosecutors with a Progressive Legal Approach Muhamad', Journal of Morality and Legal Culture, 1.2 (2020), 93-102 <https:/ / doi.org/10.20961/jmail.17i1.41087>

Najib, Ainun, 'Fatwa Majelis Ulama Indonesia Dalam Perspektif Pembangunan Hukum Responsif', 6.2 (2012), 393-405

Nasir, Mohamad Abdun, 'The 'Ulamā', Fatāwā and Challenges to Democracy in Contemporary Indonesia', Islam and Christian-Muslim Relations, 2014 <https:/ / doi.org/10.1080/09596410.2014.926598>

Noor, Hendry Julian, Kardiansyah Afkar, and Henning Glaser, 'Application of Sanctions Against State Administrative Officials Failing to Implement Administrative Court Decisions', Bestuur, 9.1 (2021), 53-67

Putri, Wulandari Berliani, Widyasari Vita, Juliet Musabula, and Muhammad Jihadul Hayat, 'Medicolegal Perspective on Physician-Induced Demand Issue', Bestuur, 9.1 (2021), 77-89

Rosidah, Zaidah Nur, 'Coherence of the Rules of Sharia Against Pancasila', 
Bestuur, 8.1 (2020), 40 <https:// doi.org/10.20961/bestuur.v8i1.42723>

Se-Indonesia, Ijtima' Ulama, Keputusan Ijtima' Ulama Komisi Fatwa Se-Indonesia Pertama Tahun 2003 (Jakarta, 2003)

Sirry, Mun'Im, 'Fatwas and Ttheir Controversy: The Case of the Council of Indonesian Ulama (MUI)', Journal of Southeast Asian Studies, 44.1 (2013), 100117

Sofian Al Hakim, 'Analytical Framwork In Studiy of Fatwas on Shariah Economics', AHKAM, 19.2 (2019), 315-30

Suhartono, Slamet, 'Eksistensi Fatwa Majelis Ulama Indonesia Dalam Perspektif Negara Hukum Pancasila', Al-Ihkam: Jurnal Hukum \& Pranata Sosial, 12.2 (2018), 448 <https:// doi.org/10.19105/al-ihkam.v12i2.1255>

Syatar, Abdul, Muhammad Majdy Amiruddin, and Arif Rahman, 'Darurat Moderasi Beragama Di Tengah Pandemi Corona Virus Desease 2019 (Covid19)', KURIOSITAS: Media Komunikasi Sosial Dan Keagamaan, 13.1 (2020), 1-13 Triasari, Devi, 'Right to Sanitation: Case Study of Indonesia', Journal of Human Rights, Culture and Legal System, 1.3 (2021)

Zakirman, Al Fakhri, 'Metodologi Fatwa Majelis Ulama Indonesia', Al-Hikmah, 10.2 (2016), 157-72 <https://doi.org/10.24260/al-hikmah.v10i2.615> 